\title{
Impact of body mass index on ovarian cancer survival varies by stage
}

\author{
Elisa V Bandera*,1,2,3, Valerie S Lee ${ }^{4}$, Bo Qin ${ }^{1}$, Lorna Rodriguez-Rodriguez ${ }^{5}$, C Bethan Powell ${ }^{6}$ \\ and Lawrence $\mathrm{H}$ Kushi $^{4}$ \\ ${ }^{1}$ Population Science, Rutgers Cancer Institute of New Jersey, 195 Little Albany Street, New Brunswick, NJ 08903, USA; \\ ${ }^{2}$ Department of Epidemiology, Rutgers School of Public Health, Piscataway, NJ 08854, USA; ${ }^{3}$ Department of Medical Oncology, \\ Robert Wood Johnson Medical School, Rutgers, The State University of New Jersey, New Brunswick, NJ 08901, USA; ${ }^{4}$ Division of \\ Research, Kaiser Permanente Northern California, Oakland, CA 94612, USA; ${ }^{5}$ Precision Medicine, Division of Gynecology \\ Oncology, Rutgers Cancer Institute of New Jersey, New Brunswick, NJ 08903, USA and ${ }^{6}$ Gynecologic Oncology Program, Kaiser \\ Permanente Northern California, San Francisco, CA 94115, USA
}

Background: Research on the effect of body mass index (BMI) on ovarian cancer survival is inconsistent, but previous studies did not consider the possible impact of ascites, bowel obstruction, or cachexia, which commonly occur in late-stage disease.

Methods: We evaluated the association of BMI, before and around the time of diagnosis, with overall and disease-specific survival in a cohort study of primary invasive epithelial ovarian cancers diagnosed from 2000 to 2013 in Kaiser Permanente Northern California (KPNC) ( $n=1184$ ). Deaths were identified through December 2014, with a median follow-up of 37 months. Proportional hazards regression was used to estimate overall and ovarian cancer-specific mortality, accounting for prognostic variables including age at diagnosis, race, stage, grade, histology, comorbidities, treatment, post-treatment CA125 levels, ascites, and bowel obstruction.

Results: There was no evidence of an association between BMI and overall or ovarian cancer-specific survival. However, we found strong effect modification by stage $\left(P_{\text {interaction }}<0.01\right)$. Compared with normal prediagnosis BMI $\left(18.5-24.9 \mathrm{~kg} \mathrm{~m}^{-2}\right)$, for women who were obese before diagnosis $\left(\mathrm{BMl} \geqslant 35 \mathrm{~kg} \mathrm{~m}^{-2}\right.$ ) ovarian cancer-specific survival was lower among those diagnosed at stages I/II (hazard ratio (HR): 3.40; 95\% confidence interval (CI): 1.16-9.99), but increased among those diagnosed with stage IV disease (HR: 0.58; 95\% Cl: 0.35-0.96). Associations were attenuated after excluding those diagnosed with cachexia $(n=82)$ and further adjustment for ascites and bowel obstruction, with no evidence of effect modification by these factors.

Conclusions: Associations of obesity with ovarian cancer survival may differ by stage, with decreased survival among those with localised disease and increased survival among those with late-stage disease. Stage-specific effects of obesity on survival suggest a tailored approach to improve prognosis may be appropriate.

Ovarian cancer is the leading cause of death from gynaecologic malignancies in the United States (American Cancer Society, 2017). Early detection of ovarian cancer remains a challenge because disease symptoms are vague and no reliable screening tests are currently available. As a consequence, only $15 \%$ of ovarian malignancies are detected at a localised stage when the disease can be cured successfully with a 5-year survival rate of $92 \%$. Unfortunately, most patients are diagnosed with regional or distant disease, with 5-year survival rates of $73 \%$ and $29 \%$, respectively (American Cancer Society, 2017). Nevertheless, although advanced ovarian cancer has a poor prognosis, cases with similar clinical and histopathological characteristics do not

*Correspondence: Dr EV Bandera; E-mail: elisa.bandera@rutgers.edu

Received 18 February 2017; revised 4 May 2017; accepted 15 May 2017; published online 6 June 2017

(C) 2017 Cancer Research UK. All rights reserved 0007-0920/17 
necessarily respond the same way to a given treatment, and some patients experience very long survival (Raspollini and Taddei, 2007). Given the uncertainties regarding the aetiology of ovarian cancer, the difficulties in early detection, and its current low survival rates, particularly when not diagnosed at an early stage, understanding the impact of modifiable factors that could improve survival among women diagnosed with ovarian cancer is of great significance.

Overall, there is growing evidence that obesity increases the risk of ovarian cancer, with several recent pooled analyses (Schouten et al, 2008; Collaborative Group on Epidemiological Studies of Ovarian Cancer, 2012; Olsen et al, 2013) and meta-analyses (Poorolajal et al, 2014; Aune et al, 2015; Liu et al, 2015) reporting consistent associations. However, the impact of body mass index (BMI) on ovarian cancer survival remains inconclusive (Purcell et al, 2016), likely due to differences in methodology and the complexity of the association. Overall, several meta-analyses have generally suggested that obesity before an ovarian cancer diagnosis might be associated with lower survival, with weaker evidence for BMI at diagnosis (Yang et al, 2011; Protani et al, 2012; Bae et al, 2014b), which has been attributed to ascites and cachexia confounding the association (Bae et al, 2014b; Purcell et al, 2016). An additional issue typically overlooked in these reports is that bowel obstruction, in some cases aggravated by inability to maintain oral intake and cachexia, is an end-of-life complication in advanced ovarian cancer (Aletti et al, 2007). Thus, it might be expected that the association of BMI and ovarian cancer survival would be different in early stage and advanced-stage patients. However, few studies have evaluated possible effect modification by disease stage. Furthermore, the majority of these studies did not have optimal study designs (e.g., based on cases in clinical trials that tend to underrepresent obese, minority women, and subjects with severe comorbidities), many relied on self-reported weight and height, most of them were able to include only women well enough to participate, and did not adjust for key prognostic factors such as treatment, and some of the previous studies even used proxy interviews likely leading to substantial misclassification.

The objective of this study was to evaluate the impact of BMI on survival, using weight and height measurements collected during patient encounters by a medical professional and other detailed clinical information in a large cohort of ovarian cancer patients, and to examine effects by key clinical characteristics.

\section{MATERIALS AND METHODS}

The Kaiser Permanente Research on Ovarian Cancer Survival (KPROCS) Study is a cohort study of ovarian cancer patients diagnosed at Kaiser Permanente Northern California (KPNC), and has been described in detail elsewhere (Bandera et al, 2015, 2016). In brief, invasive primary epithelial ovarian cancer cases at age 21 years or older and diagnosed between January 2000 and May 2013 were identified through the KPNC Cancer Registry. Data on weight and height or BMI at each patient encounter, information on diagnoses, clinical characteristics, clinical procedures, comorbidities, treatment, prescription medication use, laboratory results, and use of health-care services was obtained from the KPNC Virtual Data Warehouse files, research databases that include extracts of clinical databases from multiple sources at KPNC. To maximise treatment data completeness, women who were not KPNC members at diagnosis (i.e., became members after diagnosis), or who left KPNC before full standard chemotherapy treatment could have been completed, were excluded, resulting in a cohort of 2299 cases.

Main exposures of interest. Starting in 2002, KPNC began to include measured weight and height during patient visits in electronic records for members who had an encounter with the medical care system. We calculated BMI based on weight and height data as weight in kilograms $(\mathrm{kg})$ divided by the square of height in meters $(\mathrm{m})$ or used the BMI value if that was the available data on the electronic record. In instances where weight was available, but a contemporaneous height measurement was not, we used the height measurement closest to the weight measurement to calculate BMI. By 2005, with the introduction of the electronic medical record system, KP HealthConnect, almost $90 \%$ of the cases had their BMI data recorded electronically. Therefore, while we excluded some earlier cases for not having BMI data, this was not related to patient characteristics, but rather to changes in electronic medical record procedures, as shown in Supplementary Table 1.

Timing of available BMI data was dependent on patient visits. We operationalised the variables BMI at diagnosis and 'usual' prediagnosis BMI as follows: for BMI at diagnosis we used the measurement closest to the diagnosis date and within 6 months before diagnosis, or, if BMI was not available during that period, the closest measurement to diagnosis within 2 months after diagnosis and before treatment. We excluded 453 (19.7\%) cases that did not have BMI at diagnosis using that definition, resulting in a sample of 1846 cases. For 'usual' prediagnosis BMI we used the average value of BMI measures during the period 1-5 years before diagnosis. We compared characteristics of cases without BMI, with BMI only at diagnosis and with BMI before and at diagnosis (Supplementary Table 1) and found similar distributions by major demographic and clinical characteristics, except for the date at diagnosis, confirming that the lack of BMI data was related to the timing of implementation of recording weight and height in electronic medical records rather than to patient characteristics. Therefore, we limited our analyses to cases that had BMI information before diagnosis and at diagnosis $(n=1184)$, for consistency when comparing results.

Outcomes. The main outcomes of interest were ovarian cancerspecific mortality and overall mortality identified through the KPNC Mortality Linkage System, which includes date of death and ICD-10 coded underlying cause of death, through December 2014. Up to that date, 609 deaths, 518 from ovarian cancer, were identified in our cohort during a median follow-up of 37 months. This study was approved by the Institutional Review Boards of KPNC and Rutgers Cancer Institute of New Jersey.

Statistical analysis. Body mass index was categorised according to World Health Organisation (WHO) definitions into $<18.5 \mathrm{~kg} \mathrm{~m}^{-2}$ (underweight), $18.5-24.9 \mathrm{~kg} \mathrm{~m}^{-2}$ (normal weight), $25-29.9 \mathrm{~kg} \mathrm{~m}^{-2}$ (overweight), $30-34.9 \mathrm{~kg} \mathrm{~m}^{-2}$ (obese class I), $35-39.9 \mathrm{~kg} \mathrm{~m}^{-2}$ (obese class II), and $\geqslant 40 \mathrm{~kg} \mathrm{~m}^{-2}$ (obese class III) (International Agency for Research on Cancer, 2002). Only 27 of the cases $(2.3 \%)$ were underweight (10 before diagnosis, 21 at diagnosis, and 4 in both periods; data not shown). Therefore, underweight cases were excluded from analyses because numbers were too small to provide meaningful insight into the impact of underweight. Distributions of demographic and clinical characteristics were compared among categories of BMI using $\chi^{2}$ or Fisher's exact test, as appropriate. Mean age at diagnosis across categories of BMI were compared using ANOVA.

Survival time was calculated from the date of diagnosis to the date of death or the end of the follow-up period (December 2014). Adjusted hazard ratios (HRs) and 95\% confidence intervals (CIs) were estimated using Cox proportional hazard regression models for categories of BMI. Potential covariates considered included age at diagnosis, race/ethnicity, AJCC (American Joint Committee on Cancer) stage, grade, histology, post-treatment CA125 as a marker of residual disease (Rodriguez et al, 2012; Pelissier et al, 2014), surgery type, chemotherapy (none, paclitaxel + carboplatin regimen, other regimen), and presence of comorbidities (e.g., diabetes, hypertension, cardiovascular disease, renal disease). We focused on 
Table 1. Selected demographic and clinical characteristics by prediagnosis BMI in KP-ROCS study (2000-2014)

No. (row \%) of participants by prediagnosis BMI $\left(\mathrm{kg} \mathrm{m}^{-2}\right)$

\begin{tabular}{|c|c|c|c|c|c|c|c|}
\hline & $\begin{array}{l}\text { No. (col \%) of overall } \\
\text { cohort }^{\mathrm{a}} 1157(100)\end{array}$ & $\begin{array}{c}18.5-24.99 \\
355(30.7)\end{array}$ & $\begin{array}{c}25-29.99 \\
383(33.1)\end{array}$ & $\begin{array}{l}30-34.99 \\
218(18.8)\end{array}$ & $\begin{array}{l}35-39.99 \\
106(9.2)\end{array}$ & $\begin{array}{c}\geqslant 40 \\
95(8.2)\end{array}$ & $P$-value ${ }^{\mathrm{b}}$ \\
\hline \multicolumn{8}{|l|}{ Age at diagnosis (years) } \\
\hline $21-39$ & $36(3.1)$ & $14(38.9)$ & 7 (19.4) & $4(11.1)$ & $4(11.1)$ & $7(19.4)$ & 0.02 \\
\hline $40-49$ & $139(12.0)$ & 45 (32.4) & $42(30.2)$ & $29(20.9)$ & $14(10.1)$ & $9(6.5)$ & \\
\hline $50-69$ & $631(54.5)$ & $184(29.2)$ & $201(31.9)$ & $124(19.7)$ & $59(9.4)$ & $63(10.0)$ & \\
\hline$\geqslant 70$ & $351(30.3)$ & $112(31.9)$ & $133(37.9)$ & $61(17.4)$ & $29(8.3)$ & $16(4.6)$ & \\
\hline Mean \pm s.d. & $62.6 \pm 12.6$ & $62.8 \pm 13.4$ & $63.7 \pm 12.4$ & $62.5 \pm 12.0$ & $61.5 \pm 12.2$ & $58.2 \pm 11.4$ & 0.003 \\
\hline \multicolumn{8}{|l|}{ Race/ethnicity } \\
\hline White & $802(69.3)$ & $256(31.9)$ & $254(31.7)$ & $147(18.3)$ & $76(9.5)$ & $69(8.6)$ & $<0.001$ \\
\hline African American & $77(6.7)$ & $7(9.1)$ & $20(26.0)$ & $22(28.6)$ & $15(19.5)$ & $13(16.9)$ & \\
\hline Hispanic & $111(9.6)$ & $12(10.8)$ & $47(42.3)$ & $34(30.6)$ & $12(10.8)$ & $6(5.4)$ & \\
\hline Asian & $146(12.6)$ & $71(48.6)$ & $59(40.4)$ & $11(7.5)$ & $2(1.4)$ & $3(2.1)$ & \\
\hline Other & $21(1.8)$ & $9(42.9)$ & $3(14.3)$ & $4(19.1)$ & $1(4.8)$ & $4(19.1)$ & \\
\hline \multicolumn{8}{|c|}{$\mathrm{BMI}$ at diagnosis $\left(\mathrm{kg} \mathrm{m}^{-2}\right)$} \\
\hline Normal (18.5-24.99) & $401(34.7)$ & $323(80.6)$ & $72(18.0)$ & $5(1.3)$ & $1(0.3)$ & $0(0.0)$ & $<0.001$ \\
\hline Overweight (25-29.99) & $374(32.3)$ & $32(8.6)$ & $273(73.0)$ & $66(17.7)$ & $2(0.5)$ & $1(0.3)$ & \\
\hline Obese I (30-34.99) & $201(17.4)$ & $0(0.0)$ & 35 (17.4) & $130(64.7)$ & $32(15.9)$ & $4(2.0)$ & \\
\hline Obese II (35-39.99) & $105(9.1)$ & $0(0.0)$ & $3(2.9)$ & $16(15.2)$ & $63(60.0)$ & $23(21.9)$ & \\
\hline Obese III $(\geqslant 40)$ & $76(6.6)$ & $0(0.0)$ & $0(0.0)$ & $1(1.3)$ & $8(10.5)$ & $67(88.2)$ & \\
\hline \multicolumn{8}{|l|}{ AJCC stage } \\
\hline l & $248(21.4)$ & $80(32.3)$ & $78(31.5)$ & $47(19.0)$ & $21(8.5)$ & $22(8.9)$ & 0.96 \\
\hline II & $93(8.0)$ & $27(29.0)$ & $31(33.3)$ & 19 (20.4) & $6(6.5)$ & $10(10.8)$ & \\
\hline III & $493(42.6)$ & $149(30.2)$ & $159(32.3)$ & $94(19.1)$ & $55(11.2)$ & $36(7.3)$ & \\
\hline IV & $305(26.4)$ & $94(30.8)$ & 108 (35.4) & $55(18.0)$ & $22(7.2)$ & $26(8.5)$ & \\
\hline Unknown & $18(1.6)$ & $5(27.8)$ & 7 (38.9) & $3(16.7)$ & $2(11.1)$ & $1(5.6)$ & \\
\hline \multicolumn{8}{|l|}{ Grade (SEER definition) } \\
\hline Well differentiated & $78(6.7)$ & $23(29.5)$ & $28(35.9)$ & $11(14.1)$ & $6(7.7)$ & $10(12.8)$ & 0.71 \\
\hline Moderately differentiated & $125(10.8)$ & $37(29.6)$ & $46(36.8)$ & $20(16.0)$ & $11(8.8)$ & $11(8.8)$ & \\
\hline Poorly differentiated & $387(33.5)$ & $118(30.5)$ & $131(33.9)$ & 79 (20.4) & $31(8.0)$ & $28(7.2)$ & \\
\hline Undifferentiated & $228(19.7)$ & $76(33.3)$ & $74(32.5)$ & $46(20.2)$ & $19(8.3)$ & $13(5.7)$ & \\
\hline Unknown & $339(29.3)$ & $101(29.8)$ & $104(30.7)$ & $62(18.3)$ & $39(11.5)$ & $33(9.7)$ & \\
\hline \multicolumn{8}{|l|}{ Histology } \\
\hline Serous & $629(54.4)$ & $203(32.3)$ & $203(32.3)$ & $126(20.0)$ & $65(10.3)$ & $32(5.1)$ & 0.006 \\
\hline Mucinous & $54(4.7)$ & $18(33.3)$ & 19 (35.2) & $7(13.0)$ & $2(3.7)$ & $8(14.8)$ & \\
\hline Endometrioid & $115(9.9)$ & $27(23.5)$ & $38(33.0)$ & $21(18.3)$ & $8(7.0)$ & $21(18.3)$ & \\
\hline Clear cell & $84(7.3)$ & $27(32.1)$ & $27(32.1)$ & $16(19.1)$ & $7(8.3)$ & $7(8.3)$ & \\
\hline Other & $275(23.8)$ & $80(29.1)$ & $96(34.9)$ & $48(17.5)$ & $24(8.7)$ & $27(9.8)$ & \\
\hline \multicolumn{8}{|l|}{ Ascites at diagnosis } \\
\hline No & $770(66.6)$ & $106(27.4)$ & $120(31.0)$ & $81(20.9)$ & $43(11.1)$ & $37(9.6)$ & 0.10 \\
\hline Yes & 387 (33.5) & 249 (32.3) & $263(34.2)$ & $137(17.8)$ & $63(8.2)$ & $58(7.5)$ & \\
\hline \multicolumn{8}{|l|}{ Ascites $^{c}$} \\
\hline No & $612(52.9)$ & $200(32.7)$ & $201(32.8)$ & $113(18.5)$ & $51(8.3)$ & $47(7.7)$ & 0.52 \\
\hline Yes & $545(47.1)$ & $155(28.4)$ & $182(33.4)$ & 105 (19.3) & $55(10.1)$ & $48(8.8)$ & \\
\hline \multicolumn{8}{|l|}{ Bowel obstruction $^{c}$} \\
\hline No & $745(64.4)$ & $237(31.8)$ & $250(33.6)$ & $127(17.1)$ & $66(8.9)$ & $65(8.7)$ & 0.24 \\
\hline Yes & $412(35.6)$ & $118(28.6)$ & $133(32.3)$ & $91(22.1)$ & $40(9.7)$ & $30(7.3)$ & \\
\hline \multicolumn{8}{|l|}{ Cachexia $^{c}$} \\
\hline No & $1075(92.9)$ & $312(29.0)$ & $360(33.5)$ & $211(19.6)$ & $99(9.2)$ & $93(8.7)$ & $<0.001$ \\
\hline Yes & $82(7.1)$ & $43(52.4)$ & $23(28.1)$ & $7(8.5)$ & $7(8.5)$ & $2(2.4)$ & \\
\hline \multicolumn{8}{|l|}{ Chemotherapy } \\
\hline No & $187(16.2)$ & $59(31.6)$ & $62(33.2)$ & $35(18.7)$ & $15(8.0)$ & $16(8.6)$ & 0.86 \\
\hline Yes, carboplatin + paclitaxel & $524(45.3)$ & $155(29.6)$ & $176(33.6)$ & $107(20.4)$ & $43(8.2)$ & $43(8.2)$ & \\
\hline Yes, other regimen & $446(38.6)$ & $141(31.6)$ & $145(32.5)$ & $76(17.0)$ & $48(10.8)$ & $36(8.1)$ & \\
\hline \multicolumn{8}{|l|}{ Surgery } \\
\hline No & $70(6.1)$ & $23(32.9)$ & $20(28.6)$ & $12(17.1)$ & $8(11.4)$ & $7(10.0)$ & 0.84 \\
\hline Yes & $1087(94.0)$ & $332(30.5)$ & $363(33.4)$ & $206(19.0)$ & $98(9.0)$ & $88(8.1)$ & \\
\hline \multicolumn{8}{|l|}{ CA125 $\left(\mathrm{U} \mathrm{ml}^{-1}\right)$} \\
\hline$<35$ & $764(66.0)$ & $245(32.1)$ & 251 (32.9) & $145(19.0)$ & $65(8.5)$ & $58(7.6)$ & 0.53 \\
\hline $35-70$ & $72(6.2)$ & $28(38.9)$ & $21(29.2)$ & $10(13.9)$ & $8(11.1)$ & $5(6.9)$ & \\
\hline$>70$ & $204(17.6)$ & $55(27.0)$ & $66(32.4)$ & $39(19.1)$ & $23(11.3)$ & $21(10.3)$ & \\
\hline Unknown & $117(10.1)$ & $27(23.1)$ & 45 (38.5) & $24(20.5)$ & $10(8.5)$ & $11(9.4)$ & \\
\hline Comorbidities & & & & & & & \\
\hline Diabetes, type 2 & & & & & & & \\
\hline No & $896(77.4)$ & 318 (35.5) & 308 (34.4) & $154(17.2)$ & $67(7.5)$ & $49(5.5)$ & $<0.001$ \\
\hline Yes & $261(22.6)$ & $37(14.2)$ & $75(28.7)$ & $64(24.5)$ & $39(14.9)$ & $46(17.6)$ & \\
\hline
\end{tabular}




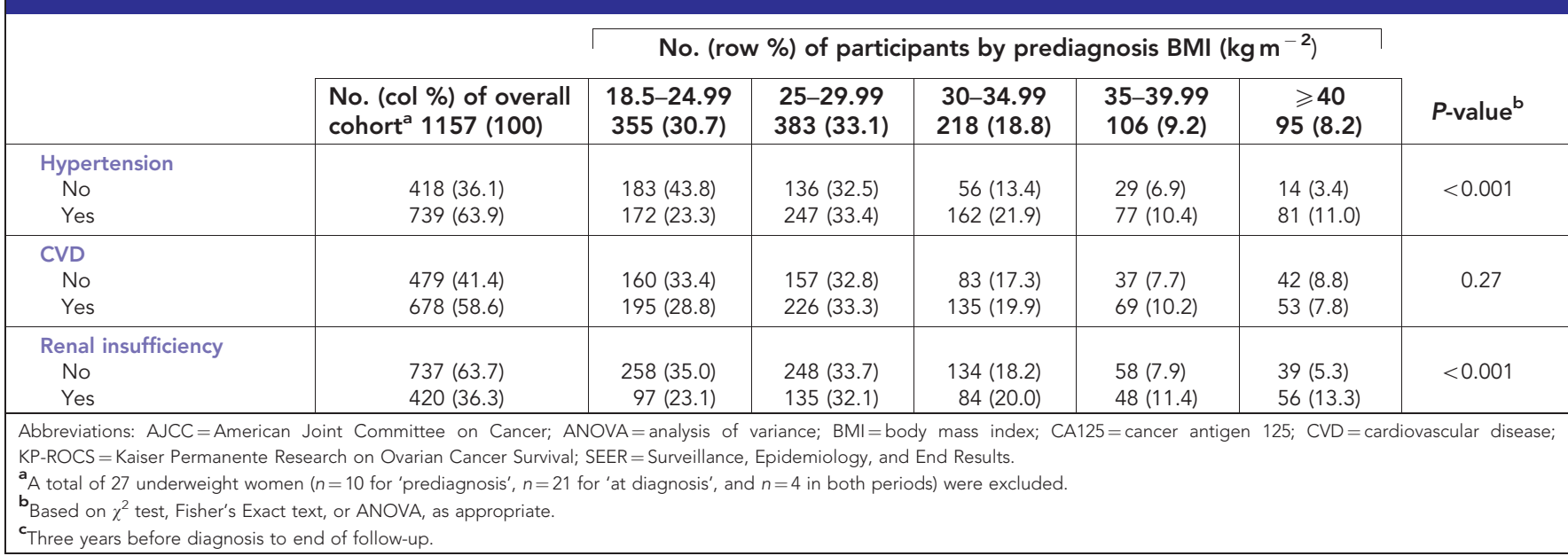

comorbidities known to be related to obesity, to impair chemotherapy dosing or survival (Stalberg et al, 2014), or to occur commonly among ovarian cancer patients (Chia et al, 2013). We also adjusted for time in months from the time of BMI measurement (or average time in the case of usual prediagnosis BMI) to diagnosis. We also considered as covariates ascites (ICD-9 code: 789.5), cachexia (ICD-9: 799.4), and bowel obstruction (ICD9: 560) occurring from 3 years before diagnosis to the end of follow-up. In sensitivity analyses we excluded women who had these conditions before diagnosis. We conducted stratified analyses to evaluate effect modification by stage, ascites, bowel obstruction, histologic type, and race/ethnicity. To maintain adequate statistical power in stratified analyses we combined the categories of class II and III obesity. Analyses were also repeated excluding women with a diagnosis of cachexia. All statistical tests were two-sided. SAS version 9.3 (SAS Institute, Cary, NC, USA) was used for analyses.

\section{RESULTS}

Demographic and clinical characteristics by prediagnosis BMI are shown in Table 1. Approximately $36 \%$ of cases were obese $\left(\mathrm{BMI}>30 \mathrm{~kg} \mathrm{~m}^{-2}\right)$ before diagnosis and $33 \%$ at diagnosis; $33 \%$ had ascites at diagnosis. Only 82 cases (7\%) had cachexia, most of them after the ovarian cancer diagnosis (98\%). Bowel obstruction occurred in 412 cases (36\%) during the study window, with $77 \%$ occurring after the ovarian cancer diagnosis. Comparing BMI before and at diagnosis, $74 \%$ remained in the same BMI category, whereas $18 \%$ lost sufficient weight from prediagnosis to the time of diagnosis to move to a lower category of BMI and $8 \%$ moved to a higher BMI category because of weight gain (Table 1). Prevalence of obesity was higher among African-American and Hispanic cases and lower in Asian cases, compared with white cases $(P<0.001)$. Obese cases $\left(\mathrm{BMI}>35 \mathrm{~kg} \mathrm{~m}^{-2}\right)$ tended to have an earlier age at diagnosis $(P=0.003)$ and were more likely to have diabetes $(P<0.001)$, hypertension $(P<0.001)$, and renal insufficiency $(P<0.001)$.

The association of prediagnosis and at diagnosis BMI with overall and ovarian cancer-specific survival is shown in Table 2. For both prediagnosis and at diagnosis BMI there was suggestion that overweight women had better overall survival, but when we excluded women with cachexia and further adjusted for ascites and bowel obstruction, estimates were not statistically significant. Overall, there was little evidence that prediagnosis obesity affected survival. Women with class III obesity $\left(\mathrm{BMI} \geqslant 40 \mathrm{~kg} \mathrm{~m}^{-2}\right)$ at diagnosis appeared to experience worse survival, but the association was attenuated and no longer statistically significant after adjusting for treatment, post-treatment CA125 levels, and comorbidities. Excluding women with cachexia and adding ascites and bowel obstruction to the model had essentially no effect on risk estimates. We conducted sensitivity analyses by further excluding women with ascites and/or bowel obstruction before diagnosis, with essentially no impact on results (data not shown).

We explored the impact of excluding women with cachexia and compared results after stratifying by ascites and bowel obstruction and by having any of these three conditions, with little evidence of effect modification (Supplementary Table 2). When we evaluated these associations by stage at diagnosis, however, a strong statistically significant interaction emerged, in which both prediagnosis and at diagnosis class II/III obesity $\left(\mathrm{BMI} \geqslant 35 \mathrm{~kg} \mathrm{~m}^{-2}\right)$ was associated with reduced ovarian cancer survival among stage I and II cases, whereas obesity was associated with better survival for those with stage IV disease $\left(P_{\text {interaction }}\right.$ for both prediagnosis and at diagnosis with stage $<0.01$ ) (Table 3). Excluding women with cachexia and further adjusting for ascites and bowel obstruction attenuated risk estimates, but for advanced-stage cases (stage IV), the significant association remained for BMI at diagnosis and for prediagnosis BMI and overall survival.

We also explored possible effect modification by race/ethnicity and by histologic type using BMI as a continuous variable and estimating the $\mathrm{HR}$ and $95 \% \mathrm{CI}$ per 5 units of BMI to maximise power, given the small numbers in the various categories (data not shown). Results were similar in the different strata of race/ethnicity or histology (serous vs non-serous).

\section{DISCUSSION}

The major finding from this study is that the association of BMI with ovarian cancer survival varies by stage. Obese women $\left(\mathrm{BMI} \geqslant 35 \mathrm{~kg} \mathrm{~m}^{-2}\right)$ with localised disease had poorer survival from ovarian cancer compared with normal-weight women, whereas obese women with advanced disease had better survival. This was seen for both BMI measured around the time of diagnosis and BMI preceding diagnosis by at least 1 year. For advanced disease, associations persisted after controlling for key prognostic factors including treatment and important clinical characteristics, such as ascites, bowel obstruction and excluding women with cachexia. In addition, there was a suggestion that being overweight may result in better overall survival among cases with localised disease (stages I and II). 
Table 2. BMI before and at diagnosis and overall and ovarian cancer-specific mortality (KP-ROCS study, 2000-2014) ${ }^{a}$

\begin{tabular}{|c|c|c|c|c|c|}
\hline & No. & Events & $\mathrm{HR}^{\mathrm{b}}(95 \% \mathrm{Cl})$ & $\mathrm{HR}^{\mathrm{c}}(95 \% \mathrm{Cl})$ & $\mathrm{HR}^{\mathrm{d}}(95 \% \mathrm{Cl})$ \\
\hline \multicolumn{6}{|l|}{ Overall mortality } \\
\hline $\begin{array}{l}\text { Prediagnosis BMI }\left(\mathrm{kg} \mathrm{m}^{-2}\right) \\
\text { Normal }(18.5-24.99) \\
\text { Overweight (25-29.99) } \\
\text { Obese I (30-34.99) } \\
\text { Obese II }(35-39.99) \\
\text { Obese III }(\geqslant 40)\end{array}$ & $\begin{array}{r}372 \\
383 \\
218 \\
106 \\
95\end{array}$ & $\begin{array}{r}185 \\
201 \\
112 \\
58 \\
50\end{array}$ & $\begin{array}{c}1 \text { (reference) } \\
0.95(0.77-1.16) \\
0.98(0.77-1.25) \\
0.96(0.71-1.31) \\
1.08(0.78-1.50)\end{array}$ & $\begin{array}{c}1 \text { (reference) } \\
0.80(0.65-0.99) \\
0.96(0.74-1.23) \\
0.89(0.64-1.22) \\
0.95(0.67-1.36)\end{array}$ & $\begin{array}{c}1 \text { (reference) } \\
0.82(0.65-1.03) \\
0.99(0.76-1.29) \\
0.92(0.65-1.30) \\
1.02(0.70-1.47)\end{array}$ \\
\hline $\begin{array}{l}\text { At-diagnosis BMI }\left(\mathrm{kg} \mathrm{m}^{-2}\right) \\
\text { Normal }(18.5-24.99) \\
\text { Overweight }(25-29.99) \\
\text { Obese I }(30-34.99) \\
\text { Obese II }(35-39.99) \\
\text { Obese III }(\geqslant 40)\end{array}$ & $\begin{array}{r}407 \\
374 \\
201 \\
105 \\
76\end{array}$ & $\begin{array}{r}205 \\
189 \\
108 \\
55 \\
40\end{array}$ & $\begin{array}{c}1 \text { (reference) } \\
0.86(0.70-1.06) \\
0.89(0.70-1.14) \\
0.85(0.62-1.16) \\
1.50(1.06-2.13)\end{array}$ & $\begin{array}{c}1 \text { (reference) } \\
0.81(0.65-0.99) \\
0.93(0.72-1.19) \\
0.87(0.63-1.20) \\
1.20(0.82-1.76)\end{array}$ & $\begin{array}{c}1 \text { (reference) } \\
0.81(0.65-1.02) \\
0.87(0.67-1.14) \\
0.82(0.57-1.16) \\
1.24(0.83-1.85)\end{array}$ \\
\hline \multicolumn{6}{|c|}{ Ovarian cancer-specific mortality } \\
\hline $\begin{array}{l}\text { Prediagnosis BMI }\left(\mathrm{kg} \mathrm{m}^{-2}\right) \\
\text { Normal }(18.5-24.99) \\
\text { Overweight (25-29.99) } \\
\text { Obese I (30-34.99) } \\
\text { Obese II }(35-39.99) \\
\text { Obese III }(\geqslant 40)\end{array}$ & $\begin{array}{r}372 \\
383 \\
218 \\
106 \\
95\end{array}$ & $\begin{array}{r}158 \\
174 \\
89 \\
51 \\
43\end{array}$ & $\begin{array}{c}1 \text { (reference) } \\
0.96(0.77-1.19) \\
0.90(0.69-1.18) \\
0.98(0.70-1.36) \\
1.10(0.77-1.56)\end{array}$ & $\begin{array}{c}1 \text { (reference) } \\
0.83(0.66-1.04) \\
0.89(0.68-1.18) \\
0.92(0.65-1.30) \\
0.96(0.66-1.40)\end{array}$ & $\begin{array}{c}1 \text { (reference) } \\
0.84(0.66-1.08) \\
0.92(0.69-1.24) \\
0.96(0.67-1.39) \\
1.01(0.68-1.50)\end{array}$ \\
\hline $\begin{array}{l}\text { At-diagnosis BMI }\left(\mathrm{kg} \mathrm{m}^{-2}\right) \\
\text { Normal }(18.5-24.99) \\
\text { Overweight }(25-29.99) \\
\text { Obese I }(30-34.99) \\
\text { Obese II }(35-39.99) \\
\text { Obese III }(\geqslant 40)\end{array}$ & $\begin{array}{r}407 \\
374 \\
201 \\
105 \\
76\end{array}$ & $\begin{array}{r}177 \\
166 \\
85 \\
47 \\
33\end{array}$ & $\begin{array}{c}1 \text { (reference) } \\
0.87(0.70-1.08) \\
0.80(0.61-1.04) \\
0.84(0.60-1.18) \\
1.43(0.97-2.10)\end{array}$ & $\begin{array}{c}1 \text { (reference) } \\
0.82(0.66-1.03) \\
0.84(0.63-1.10) \\
0.85(0.60-1.22) \\
1.15(0.75-1.74)\end{array}$ & $\begin{array}{c}1 \text { (reference) } \\
0.82(0.64-1.04) \\
0.78(0.58-1.05) \\
0.78(0.53-1.14) \\
1.17(0.75-1.81)\end{array}$ \\
\hline \multicolumn{6}{|c|}{ 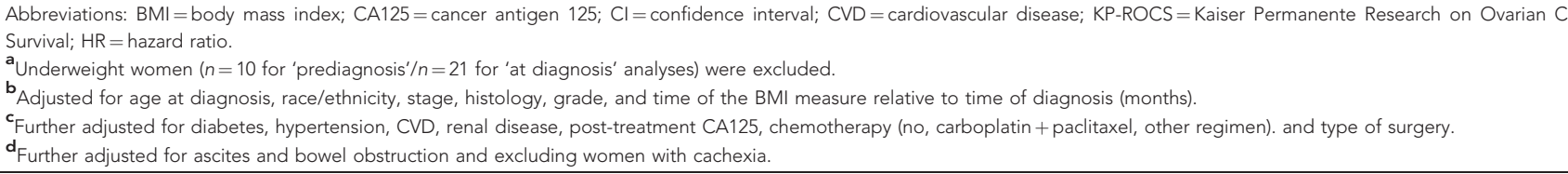 } \\
\hline
\end{tabular}

Similar to our findings for all stages combined, individual studies have generally failed to find an association between prediagnosis 'usual' BMI (Schildkraut et al, 2000; Nagle et al, 2003; Moysich et al, 2007), or BMI measured 1 year (Yang et al, 2008) or 5 years (Kotsopoulos et al, 2012) before diagnosis, and ovarian cancer survival. In contrast, two studies that evaluated BMI 5 years before diagnosis found elevated risk of death associated with higher BMI (Zhang et al, 2005; Kjaerbye-Thygesen et al, 2006). There was no association with BMI assessed at enrollment in the Women's Health Initiative with subsequent ovarian cancer mortality (Zhou et al, 2014). Similarly, the evidence for BMI at diagnosis is also inconsistent, with some studies suggesting worse (Pavelka et al, 2006; Skirnisdottir and Sorbe, 2008) or better survival for higher BMI (Zhang et al, 2005; Munstedt et al, 2008), or no association (Barrett et al, 2008; Fotopoulou et al, 2011; Suh et al, 2012). However, many of these studies did not adjust for important prognostic factors and were based on small numbers, which may explain these conflicting findings. In pooled analyses of 21 case-control studies from the Ovarian Cancer Association Consortium (Nagle et al, 2015), including over 10000 cases, BMI was associated with an $\sim 3-4 \%$ increase in total mortality per 5unit increase of BMI. The association was similar for studies evaluating BMI at diagnosis, 1 year before, or 5 years before diagnosis, but main results were only adjusted for age at diagnosis, stage, grade, and race.

Our major finding was effect modification by stage, with a $\mathrm{BMI} \geqslant 35 \mathrm{~kg} \mathrm{~m}^{-2}$ being associated with reduced ovarian cancerspecific survival among stage I/II cases, while there was a clear dose-response association with better survival among those with stage IV disease. We are aware of only one other study that stratified by stage in which HRs (95\% CI) for ovarian cancer deaths comparing obese vs normal weight women was 0.86 (95\% CI: 0.35-2.12) and 1.31 (0.90-1.90) for those diagnosed with stage I/II and stage III/IV disease, respectively (Yang et al, 2008). These analyses were based on very small numbers and only adjusted for stage, grade, and age at diagnosis. An additional study of advanced ovarian cancer (stage III/IV, $n=236$ cases) reported better survival for overweight and obese women among serous cases with optimal surgery (Bae et al, 2014a), somewhat consistent with our findings. Similar effect modification by stage was recently reported for prediagnosis BMI and colorectal cancer survival in a large consortium of six prospective studies, with higher BMI increasing mortality risk only for early-stage cases, while decreasing risk for advanced-stage cases (Kocarnik et al, 2016).

The finding of better survival for those with higher BMI among advanced cases is congruent with the 'obesity paradox', the well known but controversial observation that among people with severe illness, obesity seems to be associated with longer survival (Childers and Allison, 2010). Confounding is sometimes offered as a possible explanation. However, in our study the association persisted after controlling for major prognostic factors, including treatment and the presence of ascites and bowel obstruction. Advanced disease patients are more likely to experience ascites, bowel obstruction, and cachexia, which may lead to malnutrition. The metabolic reserves of stored body fat in these patients may help them withstand treatment and cope with the physiological stress caused by disease (Kocarnik et al, 2016). There is also some suggestion that immune function is better among obese patients in times of biological stress or trauma (Childers and Allison, 2010). Another issue is the fact that BMI does not capture differences in body composition (e.g., fat mass $v s$ fat-free mass) that may occur during treatment and disease progression (Purcell et al, 2016). Furthermore, results did not change after excluding women with a diagnosis of cachexia. However, cachexia status may have been misclassified in our study. Studies are needed to evaluate the impact of body composition on ovarian cancer survival. 
Table 3. BMI before and at diagnosis and overall and ovarian cancer-specific mortality by stage (KP-ROCS Study, 2000-2014)

\begin{tabular}{|c|c|c|c|c|c|c|}
\hline & \multicolumn{2}{|c|}{ Stage I/II } & \multicolumn{2}{|c|}{ Stage III } & \multicolumn{2}{|c|}{ Stage IV } \\
\hline & $\mathrm{HR}^{\mathrm{b}}(95 \% \mathrm{Cl})$ & $\mathrm{HR}^{\mathrm{c}}(95 \% \mathrm{Cl})$ & $\mathrm{HR}^{\mathrm{b}}(95 \% \mathrm{Cl})$ & $\mathrm{HR}^{\mathrm{c}}(95 \% \mathrm{Cl})$ & $\mathrm{HR}^{\mathrm{b}}(95 \% \mathrm{Cl})$ & $\mathrm{HR}^{\mathrm{c}}(95 \% \mathrm{Cl})$ \\
\hline \multicolumn{7}{|l|}{ Overall mortality } \\
\hline $\begin{array}{l}\text { Prediagnosis BMI }\left(\mathrm{kg} \mathrm{m}^{-2}\right) \\
\text { Normal }(18.5-24.99) \\
\text { Overweight }(25-29.99) \\
\text { Obese I }(30-34.99) \\
\text { Obese II/III }(\geqslant 35) \\
P_{\text {interaction }}\end{array}$ & $\begin{array}{c}\text { n/events: } 345 / 60 \\
1 \text { (reference) } \\
0.36 \text { (0.15-0.88) } \\
0.76 \text { (0.31-1.88) } \\
1.85 \text { (0.76-4.47) }\end{array}$ & $\begin{array}{c}334 / 56 \\
1 \text { (reference) } \\
0.33(0.13-0.87) \\
0.93(0.37-2.35) \\
1.71(0.69-4.28)\end{array}$ & $\begin{array}{c}501 / 292 \\
1 \text { (reference) } \\
0.83(0.60-1.15) \\
1.52(1.04-2.22) \\
1.12(0.74-1.72)\end{array}$ & $\begin{array}{c}458 / 256 \\
1 \text { (reference) } \\
0.79(0.55-1.13) \\
1.35(0.90-2.02) \\
1.14(0.71-1.84)\end{array}$ & $\begin{array}{c}310 / 240 \\
1 \text { (reference) } \\
0.80(0.56-1.14) \\
0.65(0.42-1.00) \\
0.56(0.35-0.89) \\
0.002\end{array}$ & $\begin{array}{c}278 / 213 \\
1 \text { (reference) } \\
0.73(0.49-1.08) \\
0.63(0.40-1.01) \\
0.54(0.33-0.88) \\
0.001\end{array}$ \\
\hline $\begin{array}{l}\text { At-diagnosis BMI }\left(\mathrm{kg} \mathrm{m}^{-2}\right) \\
\text { Normal }(18.5-24.99) \\
\text { Overweight }(25-29.99) \\
\text { Obese I }(30-34.99) \\
\text { Obese II/III }(\geqslant 35) \\
P_{\text {interaction }}\end{array}$ & $\begin{array}{c}\text { n/events: } 345 / 59 \\
1 \text { (reference) } \\
0.38 \text { (0.15-0.92) } \\
0.99(0.40-2.48) \\
1.97 \text { (0.75-5.14) }\end{array}$ & $\begin{array}{c}334 / 55 \\
1 \text { (reference) } \\
0.40(0.15-1.05) \\
1.14(0.45-2.90) \\
1.93(0.74-5.05)\end{array}$ & $\begin{array}{c}494 / 288 \\
1 \text { (reference) } \\
0.98(0.72-1.34) \\
1.28(0.86-1.89) \\
1.30(0.86-1.96)\end{array}$ & $\begin{array}{c}453 / 253 \\
1 \text { (reference) } \\
0.90(0.64-1.27) \\
1.01(0.66-1.55) \\
1.18(0.74-1.88)\end{array}$ & $\begin{array}{c}306 / 236 \\
1 \text { (reference) } \\
0.74(0.52-1.06) \\
0.78(0.51-1.20) \\
0.54(0.32-0.91) \\
0.003\end{array}$ & $\begin{array}{c}276 / 210 \\
1 \text { (reference) } \\
0.77(0.52-1.14) \\
0.83(0.52-1.31) \\
0.56(0.32-0.98) \\
0.002\end{array}$ \\
\hline \multicolumn{7}{|c|}{ Ovarian cancer-specific mortality } \\
\hline $\begin{array}{l}\text { Prediagnosis BMI }\left(\mathrm{kg} \mathrm{m}^{-2}\right) \\
\text { Normal }(18.5-24.99) \\
\text { Overweight }(25-29.99) \\
\text { Obese I (30-34.99) } \\
\text { Obese II/III }(\geqslant 35) \\
\text { Pinteraction }\end{array}$ & $\begin{array}{c}\text { n/events: } 345 / 42 \\
1 \text { (reference) } \\
0.55(0.19-1.61) \\
0.79(0.25-2.53) \\
3.40(1.16-9.99)\end{array}$ & $\begin{array}{c}334 / 39 \\
1 \text { (reference) } \\
0.49(0.15-1.61) \\
0.88(0.26-2.97) \\
2.80(0.88-8.93)\end{array}$ & $\begin{array}{c}501 / 257 \\
1 \text { (reference) } \\
0.75(0.53-1.05) \\
1.28(0.86-1.93) \\
1.02(0.65-1.59)\end{array}$ & $\begin{array}{c}458 / 223 \\
1 \text { (reference) } \\
0.69(0.47-1.00) \\
1.12(0.72-1.73) \\
1.01(0.61-1.68)\end{array}$ & $\begin{array}{c}310 / 203 \\
1 \text { (reference) } \\
0.87(0.59-1.28) \\
0.65(0.40-1.04) \\
0.58(0.35-0.96) \\
0.003\end{array}$ & $\begin{array}{c}278 / 181 \\
1 \text { (reference) } \\
0.84(0.55-1.28) \\
0.67(0.40-1.11) \\
0.58(0.34-1.00) \\
0.005\end{array}$ \\
\hline $\begin{array}{l}\text { At-diagnosis BMI }\left(\mathrm{kg} \mathrm{m}^{-2}\right) \\
\text { Normal }(18.5-24.99) \\
\text { Overweight }(25-29.99) \\
\text { Obese I }(30-34.99) \\
\text { Obese II/III }(\geqslant 35) \\
P_{\text {interaction }} \\
\end{array}$ & $\begin{array}{l}\text { n/events: } 345 / 41 \\
1 \text { (reference) } \\
0.51 \text { (0.18-1.44) } \\
1.05 \text { (0.33-3.32) } \\
3.22 \text { (1.02-10.15) }\end{array}$ & $\begin{array}{c}334 / 38 \\
1 \text { (reference) } \\
0.57(0.18-1.75) \\
1.08(0.32-3.58) \\
2.79(0.85-9.19)\end{array}$ & $\begin{array}{c}494 / 254 \\
1 \text { (reference) } \\
0.91 \text { (0.66-1.26) } \\
1.11(0.73-1.68) \\
1.15(0.74-1.79)\end{array}$ & $\begin{array}{c}453 / 221 \\
1 \text { (reference) } \\
0.80(0.56-1.15) \\
0.82(0.52-1.29) \\
1.00(0.60-1.64)\end{array}$ & $\begin{array}{c}306 / 200 \\
1 \text { (reference) } \\
0.78(0.53-1.14) \\
0.68(0.43-1.09) \\
0.50(0.28-0.90) \\
0.001 \\
\end{array}$ & $\begin{array}{c}276 / 179 \\
1 \text { (reference) } \\
0.84(0.56-1.27) \\
0.79(0.48-1.31) \\
0.55(0.30-1.01) \\
0.001 \\
\end{array}$ \\
\hline \multicolumn{7}{|c|}{ 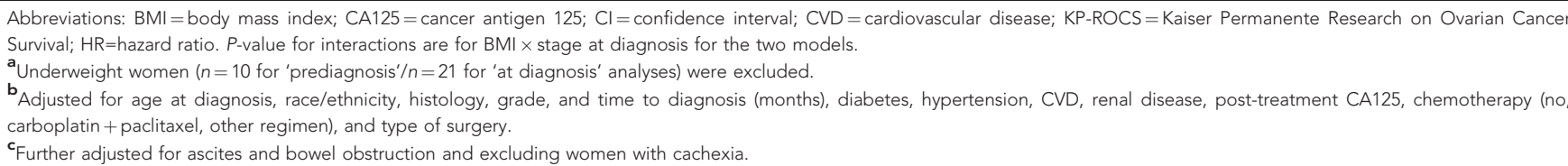 } \\
\hline
\end{tabular}

Among cases diagnosed with stage I/II disease, we found a $\mathrm{BMI} \geqslant 35 \mathrm{~kg} \mathrm{~m}^{-2}$ was associated with reduced ovarian cancer survival after adjusting for major prognostic factors, such as histology, grade, treatment, post-treatment CA125, and comorbidities. Adjusting further for ascites and bowel obstruction and excluding those with cachexia resulted in qualitatively similar but attenuated associations. Given the relatively small number of deaths among early-stage cases, statistical power was limited and CIs included the null, but our findings suggest reduced survival among those with high BMI levels. Several interrelated mechanisms involving hormonal pathways have been proposed to explain a possible role of obesity on cancer survival (Hursting and Berger, 2010; Institute of Medicine, 2012; Parekh et al, 2012). These include effects on insulin resistance and insulin-like growth factor-I and increased aromatisation of androstenedione to oestrone in peripheral adipocytes, thus increasing the bioavailabiltiy of sex steroids and adrenal and ovarian secretion of androgens. Higher circulating oestrogen levels may stimulate ovarian cancer proliferation, resulting in faster growth of metastatic tissue (Kjaerbye-Thygesen et al, 2006). Obesity is also known to induce chronic inflammation and to impair immune function (McTiernan, 2006; Hursting and Berger, 2010). There is also a direct association between obesity and C-reactive protein (CRP), a marker of systemic inflammation (Fogarty et al, 2008). At the same time, higher serum CRP levels have been shown to be an independent predictor of lower ovarian cancer survival (Hefler et al, 2008). Adipokines (e.g., leptin and adiponectin), inflammatory cytokines produced by adipocytes, have also been hypothesised to play a role in tumour development and progression (Parekh et al, 2012), although there is inconsistent evidence regarding their role on ovarian cancer survival (Diaz et al, 2013; Kato et al, 2015). Overall, these hormonal and metabolic changes associated with greater adiposity favor progressive genetic instability, tumour growth, tumour progression, and metastases (Hursting and Berger, 2010). In addition, because obesity is a strong predictor of dose reduction (Bandera et al, 2015), it is possible that receiving suboptimal chemotherapy dosing may contribute to the observed lower survival in early-stage cases.

Because other studies have suggested that the association between BMI and ovarian cancer survival may vary by histologic subtype (Nagle et al, 2015), we attempted to explore this, but numbers in the different histologic subtypes only allowed us to evaluate associations in serous $v s$ non-serous cases, with similar results (data not shown). Similarly, because of the known racial disparities in ovarian cancer survival, with African-American women experiencing the worse survival (Chornokur et al, 2013; Bandera et al, 2016), we explored the association of obesity with ovarian cancer survival by race/ethnicity and found no differential effects (data not shown), but these analyses had limited statistical power. Larger studies in multiethnic populations are required to further explore these associations.

Our study is the first with sufficient detailed clinical information to evaluate fully the role of BMI on ovarian cancer survival while taking into account important clinical factors. Because of the large number of cases we were able to examine the association by stage at diagnosis. Using measured BMI from medical records is another strength of this study. Furthermore, our findings are based on a representative large sample of ovarian cancer patients, not based on a single institution, or on patients entering a specific clinical trial protocol, which by definition may be too homogeneous to be generalisable. Overall, KPNC membership comprises $\sim 30 \%$ of the population in the areas served by KPNC. Members are similar to the general population in terms of employment status, marital 
status, screening practices, and prevalence of medical conditions, when compared with population-based data from the California Behavioral Risk Factor Surveillance System (Gordon, 1997). Case identification and vital status ascertainment was conducted through the KPNC Cancer Registry, which follows data quality and reporting standards of the North American Association of Centralised Cancer Registries and the NCI SEER Program. The distributions of stage at diagnosis (Goodman et al, 2003; Kaiser Permanente Northern California Cancer Registry at the Division of Research, 2011) and mortality by stage (Kaiser Permanente Northern California Cancer Registry at the Division of Research, 2011) among KPNC cases are similar to SEER estimates, which supports the external validity of our findings.

In summary, in this study, the association of obesity with ovarian cancer survival varied by stage, with possible worse survival for those with localised disease, whereas those with advanced disease experienced better survival. Our findings need replication with evaluation of body composition and histologic subtype. Maintaining a healthy weight remains an important goal for the prevention of cancer and other chronic diseases. However, in the case of advanced disease, caution should be exercised in issuing recommendations, as increased body fatness may confer some survival advantages.

\section{ACKNOWLEDGEMENTS}

This work was supported by grants from the National Cancer Institute at the National Institutes of Health (K22 CA138563 and U24 CA171524).

\section{CONFLICT OF INTEREST}

The authors declare no conflict of interest.

\section{REFERENCES}

Aletti GD, Gallenberg MM, Cliby WA, Jatoi A, Hartmann LC (2007) Current management strategies for ovarian cancer. Mayo Clin Proc 82(6): 751-770.

American Cancer Society (2017) Cancer Facts and Figures. American Cancer Society: Atlanta, GA, USA.

Aune D, Navarro Rosenblatt DA, Chan DS, Abar L, Vingeliene S, Vieira AR, Greenwood DC, Norat T (2015) Anthropometric factors and ovarian cancer risk: a systematic review and nonlinear dose-response metaanalysis of prospective studies. Int J Cancer 136(8): 1888-1898.

Bae HS, Hong JH, Ki KD, Song JY, Shin JW, Lee JM, Lee JK, Lee NW, Lee C, Lee KW, Kim YM (2014a) The effect of body mass index on survival in advanced epithelial ovarian cancer. J Korean Med Sci 29(6): 793-797.

Bae HS, Kim HJ, Hong JH, Lee JK, Lee NW, Song JY (2014b) Obesity and epithelial ovarian cancer survival: a systematic review and meta-analysis. J Ovarian Res 7: 41.

Bandera EV, Lee VS, Rodriguez-Rodriguez L, Powell CB, Kushi LH (2015) Impact of chemotherapy dosing on ovarian cancer survival according to body mass index. JAMA Oncol 1(6): 737-745.

Bandera EV, Lee VS, Rodriguez-Rodriguez L, Powell CB, Kushi LH (2016) Racial/ethnic disparities in ovarian cancer treatment and survival. Clin Cancer Res 22(23): 5909-5914.

Barrett SV, Paul J, Hay A, Vasey PA, Kaye SB, Glasspool RM, Scottish Gynaecological Cancer Trials G (2008) Does body mass index affect progression-free or overall survival in patients with ovarian cancer? Results from SCOTROC I trial. Ann Oncol 19(5): 898-902.

Chia VM, O’Malley CD, Danese MD, Lindquist KJ, Gleeson ML, Kelsh MA, Griffiths RI (2013) Prevalence and incidence of comorbidities in elderly women with ovarian cancer. Gynecol Oncol 129(2): 346-352.

Childers DK, Allison DB (2010) The 'obesity paradox': a parsimonious explanation for relations among obesity, mortality rate and aging? Int $J$ Obes (Lond) 34(8): 1231-1238.
Chornokur G, Amankwah EK, Schildkraut JM, Phelan CM (2013) Global ovarian cancer health disparities. Gynecol Oncol 129(1): 258-264.

Collaborative Group on Epidemiological Studies of Ovarian Cancer (2012) Ovarian cancer and body size: individual participant meta-analysis including 25,157 women with ovarian cancer from 47 epidemiological studies. PLoS Med 9(4): e1001200.

Diaz ES, Karlan BY, Li AJ (2013) Obesity-associated adipokines correlate with survival in epithelial ovarian cancer. Gynecol Oncol 129(2): 353-357.

Fogarty AW, Glancy C, Jones S, Lewis SA, McKeever TM, Britton JR (2008) A prospective study of weight change and systemic inflammation over $9 \mathrm{y}$. Am J Clin Nutr 87(1): 30-35.

Fotopoulou C, Richter R, Braicu EI, Kuhberg M, Feldheiser A, Schefold JC, Lichtenegger W, Sehouli J (2011) Impact of obesity on operative morbidity and clinical outcome in primary epithelial ovarian cancer after optimal primary tumor debulking. Ann Surg Oncol 18(9): 2629-2637.

Goodman MT, Correa CN, Tung KH, Roffers SD, Cheng WuX, Young Jr JL, Wilkens LR, Carney ME, Howe HL (2003) Stage at diagnosis of ovarian cancer in the United States, 1992-1997. Cancer 97(10, Suppl): 2648-2659.

Gordon N (1997) Comparison of Northern California Kaiser Permanente Population to General Population. Kaiser Permanente: Oakland, CA, USA.

Hefler LA, Concin N, Hofstetter G, Marth C, Mustea A, Sehouli J, Zeillinger R, Leipold H, Lass H, Grimm C, Tempfer CB, Reinthaller A (2008) Serum C-reactive protein as independent prognostic variable in patients with ovarian cancer. Clin Cancer Res 14(3): 710-714.

Hursting SD, Berger NA (2010) Energy balance, host-related factors, and cancer progression. J Clin Oncol 28(26): 4058-4065.

Institute of Medicine (2012) The Role of Obesity in Cancer Survival and Recurrence: Workshop Summary. Kaiser Permanente: Washington, DC, USA.

International Agency for Research on Cancer (2002) IARC Handbooks of Cancer Prevention. Vol. 6. Weight Control and Physical Activity. World Health Organization: Lyon, France.

Kaiser Permanente Northern California Cancer Registry at the Division of Research (2011) Annual Report on Trends, Incidence, and Outcomes. Summarizing Data Reported to the California Cancer Registry and the SEER Program of the National Cancer Institute. Kaiser Permanente of Northern California: Oakland, CA, USA.

Kato S, Abarzua-Catalan L, Trigo C, Delpiano A, Sanhueza C, Garcia K, Ibanez C, Hormazabal K, Diaz D, Branes J, Castellon E, Bravo E, Owen G, Cuello MA (2015) Leptin stimulates migration and invasion and maintains cancer stem-like properties in ovarian cancer cells: an explanation for poor outcomes in obese women. Oncotarget 6(25): 21100-21119.

Kjaerbye-Thygesen A, Frederiksen K, Hogdall EV, Glud E, Christensen L, Hogdall CK, Blaakaer J, Kjaer SK (2006) Smoking and overweight: negative prognostic factors in stage III epithelial ovarian cancer. Cancer Epidemiol Biomarkers Prev 15(4): 798-803.

Kocarnik JM, Chan AT, Slattery ML, Potter JD, Meyerhardt J, Phipps A, Nan H, Harrison T, Rohan TE, Qi L, Hou L, Caan B, Kroenke CH, Strickler H, Hayes RB, Schoen RE, Chong DQ, White E, Berndt SI, Peters U, Newcomb PA (2016) Relationship of pre-diagnostic body mass index with survival after colorectal cancer: Stage-specific associations. Int $J$ Cancer 139(5): 1065-1072.

Kotsopoulos J, Moody JR, Fan I, Rosen B, Risch HA, McLaughlin JR, Sun P, Narod SA (2012) Height, weight, BMI and ovarian cancer survival. Gynecol Oncol 127(1): 83-87.

Liu Y, Metzinger MN, Lewellen KA, Cripps SN, Carey KD, Harper EI, Shi Z, Tarwater L, Grisoli A, Lee E, Slusarz A, Yang J, Loughran EA, Conley K, Johnson JJ, Klymenko Y, Bruney L, Liang Z, Dovichi NJ, Cheatham B, Leevy WM, Stack MS (2015) Obesity contributes to ovarian cancer metastatic success through increased lipogenesis, enhanced vascularity, and decreased infiltration of M1 macrophages. Cancer Res 75(23): 5046-5057.

McTiernan A (2006) Weight management in the breast cancer survivor. In: Heber D, Blackburn GL, Go VLW, Milner J (eds) Nutritional Oncology, 2nd edn. Academic Press: San Diego, CA, USA.

Moysich KB, Baker JA, Menezes RJ, Jayaprakash V, Rodabaugh KJ, Odunsi K, Beehler GP, McCann SE, Villella JA (2007) Usual adult body mass index is not predictive of ovarian cancer survival. Cancer Epidemiol Biomarkers Prev 16(3): 626-628.

Munstedt K, Wagner M, Kullmer U, Hackethal A, Franke FE (2008) Influence of body mass index on prognosis in gynecological malignancies. Cancer Causes Control 19(9): 909-916. 
Nagle CM, Dixon SC, Jensen A, Kjaer SK, Modugno F, deFazio A, Fereday S, Hung J, Johnatty SE. Australian Ovarian Cancer Study GFasching PA, Beckmann MW, Lambrechts D, Vergote I, Van Nieuwenhuysen E, Lambrechts S, Risch HA, Rossing MA, Doherty JA, Wicklund KG, Chang-Claude J, Goodman MT, Ness RB, Moysich K, Heitz F, du Bois A, Harter P, Schwaab I, Matsuo K, Hosono S, Goode EL, Vierkant RA, Larson MC, Fridley BL, Hogdall C, Schildkraut JM, Weber RP, Cramer DW, Terry KL, Bandera EV, Paddock L, Rodriguez-Rodriguez L, Wentzensen N, Yang HP, Brinton LA, Lissowska J, Hogdall E, Lundvall L, Whittemore A, McGuire V, Sieh W, Rothstein J, Sutphen R, Anton-Culver H, Ziogas A, Pearce CL, Wu AH, Webb PM, Ovarian Cancer Association C (2015) Obesity and survival among women with ovarian cancer: results from the Ovarian Cancer Association Consortium. Br J Cancer 113(5): 817-826.

Nagle CM, Purdie DM, Webb PM, Green A, Harvey PW, Bain CJ (2003) Dietary influences on survival after ovarian cancer. Int J Cancer 106(2): 264-269.

Olsen CM, Nagle CM, Whiteman DC, Ness R, Pearce CL, Pike MC, Rossing MA, Terry KL, Wu AH, Australian Cancer S, Australian Ovarian Cancer Study G, Risch HA, Yu H, Doherty JA, Chang-Claude J, Hein R, Nickels S, Wang-Gohrke S, Goodman MT, Carney ME, Matsuno RK, Lurie G, Moysich K, Kjaer SK, Jensen A, Hogdall E, Goode EL, Fridley BL, Vierkant RA, Larson MC, Schildkraut J, Hoyo C, Moorman P, Weber RP, Cramer DW, Vitonis AF, Bandera EV, Olson SH, Rodriguez-Rodriguez L, King M, Brinton LA, Yang H, Garcia-Closas M, Lissowska J, Anton-Culver H, Ziogas A, Gayther SA, Ramus SJ, Menon U, Gentry-Maharaj A, Webb PM, Ovarian Cancer Association C (2013) Obesity and risk of ovarian cancer subtypes: evidence from the Ovarian Cancer Association Consortium. Endocr Relat Cancer 20(2): 251-262.

Parekh N, Chandran U, Bandera EV (2012) Obesity in cancer survival. Annu Rev Nutr 32: 311-342.

Pavelka JC, Brown RS, Karlan BY, Cass I, Leuchter RS, Lagasse LD, Li AJ (2006) Effect of obesity on survival in epithelial ovarian cancer. Cancer 107(7): 1520-1524.

Pelissier A, Bonneau C, Chereau E, de La Motte Rouge T, Fourchotte V, Darai E, Rouzier R (2014) CA125 kinetic parameters predict optimal cytoreduction in patients with advanced epithelial ovarian cancer treated with neoadjuvant chemotherapy. Gynecol Oncol 135(3): 542-546.

Poorolajal J, Jenabi E, Masoumi SZ (2014) Body mass index effects on risk of ovarian cancer: a meta- analysis. Asian Pac J Cancer Prev 15(18): 7665-7671.

Protani MM, Nagle CM, Webb PM (2012) Obesity and ovarian cancer survival: a systematic review and meta-analysis. Cancer Prev Res (Phila) 5(7): 901-910.

Purcell SA, Elliott SA, Kroenke CH, Sawyer MB, Prado CM (2016) Impact of body weight and body composition on ovarian cancer prognosis. Curr Oncol Rep 18(2): 8.
Raspollini MR, Taddei GL (2007) Tumor markers in ovarian carcinoma. Int J Gynaecol Obstet 97(3): 175-181.

Rodriguez N, Rauh-Hain JA, Shoni M, Berkowitz RS, Muto MG, Feltmate C, Schorge JO, Del Carmen MG, Matulonis UA, Horowitz NS (2012) Changes in serum CA-125 can predict optimal cytoreduction to no gross residual disease in patients with advanced stage ovarian cancer treated with neoadjuvant chemotherapy. Gynecol Oncol 125(2): 362-366.

Schildkraut JM, Halabi S, Bastos E, Marchbanks PA, McDonald JA, Berchuck A (2000) Prognostic factors in early-onset epithelial ovarian cancer: a population-based study. Obstet Gynecol 95(1): 119-127.

Schouten LJ, Rivera C, Hunter DJ, Spiegelman D, Adami HO, Arslan A, Beeson WL, van den Brandt PA, Buring JE, Folsom AR, Fraser GE, Freudenheim JL, Goldbohm RA, Hankinson SE, Lacey Jr JV, Leitzmann M, Lukanova A, Marshall JR, Miller AB, Patel AV, Rodriguez C, Rohan TE, Ross JA, Wolk A, Zhang SM, Smith-Warner SA (2008) Height, body mass index, and ovarian cancer: a pooled analysis of 12 cohort studies. Cancer Epidemiol Biomarkers Prev 17(4): 902-912.

Skirnisdottir I, Sorbe B (2008) Prognostic impact of body mass index and effect of overweight and obesity on surgical and adjuvant treatment in early-stage epithelial ovarian cancer. Int J Gynecol Cancer 18(2): 345-351.

Stalberg K, Svensson T, Lonn S, Kieler H (2014) The influence of comorbidity on mortality in ovarian cancer patients. Gynecol Oncol 133(2): 298-303.

Suh DH, Kim HS, Chung HH, Kim JW, Park NH, Song YS, Kang SB (2012) Body mass index and survival in patients with epithelial ovarian cancer. J Obstet Gynaecol Res 38(1): 70-76.

Yang HS, Yoon C, Myung SK, Park SM (2011) Effect of obesity on survival of women with epithelial ovarian cancer: a systematic review and metaanalysis of observational studies. Int J Gynecol Cancer 21(9): 1525-1532.

Yang L, Klint A, Lambe M, Bellocco R, Riman T, Bergfeldt K, Persson I, Weiderpass E (2008) Predictors of ovarian cancer survival: a populationbased prospective study in Sweden. Int J Cancer 123(3): 672-679.

Zhang M, Xie X, Lee AH, Binns CW, Holman CD (2005) Body mass index in relation to ovarian cancer survival. Cancer Epidemiol Biomarkers Prev 14(5): 1307-1310.

Zhou Y, Chlebowski R, LaMonte MJ, Bea JW, Qi L, Wallace R, Lavasani S, Walsh BW, Anderson G, Vitolins M, Sarto G, Irwin ML (2014) Body mass index, physical activity, and mortality in women diagnosed with ovarian cancer: results from the Women's Health Initiative. Gynecol Oncol 133(1): 4-10.

This work is published under the standard license to publish agreement. After 12 months the work will become freely available and the license terms will switch to a Creative Commons AttributionNonCommercial-Share Alike 4.0 Unported License.

Supplementary Information accompanies this paper on British Journal of Cancer website (http://www.nature.com/bjc) 